\title{
Perception of virtual classroom interaction and level of soft skills in college students
}

\author{
Julio Éfrain Postigo-Zumaráni \\ Continental University, Huancayo, Peru \\ Dennis Arias-Chávezi \\ Continental University, Huancayo, Peru

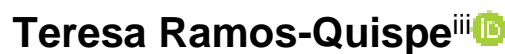 \\ National University of San Agustín de Arequipa, Arequipa, Peru
}

\begin{abstract}
The purpose of this study is to specify the relationship between the perception of classroom interaction and the level of soft skills. A cross-cutting, correlal observational study was conducted on a sample of 507 students from the seventh to tenth cycle of the branch's professional schools in Arequipa from a private Peruvian university, recruited electronically in 2020. The instruments applied were the Virtual Classroom Interaction Perception Scale and the Soft Skills Scale. The results show the existence of a positive weak relationship between the perception of virtual classroom interaction and soft skills. The correlation was 114 , the size of the effect is medium, being 0.3376389 . In terms of statistical power, the value exceeds 0.80 , obtaining the value of 0.950 . It is concluded that there is a significant and positive relationship between the variables, even though the relationship between the two variables is weak.
\end{abstract}

\section{Keywords}

Virtual classroom interaction. Soft skills. College students. College teachers.

\section{Percepção de interação em sala de aula virtual e nível de habilidades sociais em estudantes universitários}

\begin{abstract}
Resumo
O objetivo deste estudo é especificar a relação entre a percepção da interação em sala de aula e o nível de habilidades sociais. Foi realizado um estudo observacional transversal e correlacional em uma amostra de 507 alunos do sétimo ao décimo ciclo das escolas profissionais da filial em Arequipa de uma universidade privada peruana, recrutados eletronicamente em 2020. Os instrumentos aplicados foram a Escala de Percepção de Interação em Sala de Aula Virtual e a Escala de Habilidades Suaves. Os resultados mostram a existência de uma fraca relação positiva entre a percepção de interação em sala de aula virtual e as habilidades sociais. A correlação foi de 0,114 , o tamanho do efeito é médio, sendo 0,3376389. Em termos de poder estatístico, o valor ultrapassa 0,80, obtendo-se o valor de 0,950. Conclui-se que existe uma relação significativa e positiva entre as variáveis, embora a relação entre as duas variáveis seja fraca.
\end{abstract}

\section{Palavras-chave}

Interação em sala de aula virtual. Habilidades sociais. Estudantes universitários. Professores universitários. 


\title{
Percepción de interacción en el aula virtual y nivel
} de habilidades sociales en estudiantes universitarios

\begin{abstract}
Resumen
El propósito de este estudio es especificar la relación entre la percepción de la interacción en el aula y el nivel de habilidades blandas. Se realizó un estudio observacional, transversal y correlal, en una muestra de 507 estudiantes del séptimo al décimo ciclo de las escuelas profesionales de la filial en Arequipa de una universidad privada peruana, reclutados electrónicamente en 2020. Los instrumentos aplicados fueron la Escala de Percepción de Interacción en el Aula Virtual y la escala de habilidades blandas. Los resultados muestran la existencia de una relación débil positiva entre la percepción de la interacción en el aula virtual y las habilidades blandas. La correlación fue .114, el tamaño del efecto es medio, siendo 0.3376389 . En términos de potencia estadística, el valor supera el 0,80 , obteniendo el valor de 0,950. Se concluye que existe una relación significativa y positiva entre las variables, aunque la relación entre las dos variables es débil.
\end{abstract}

\section{Palabras clave}

Interacción en el aula virtual. Habilidades blandas. Estudiantes universitarios. Profesores universitarios.

\section{Introduction}

In virtual learning environments it is important for students to use web space information to assimilate content (HASSAN et al., 2004). This use has a direct impact on the efficiency and satisfaction of this sector since these spaces are designed and organized according to the needs and characteristics of those who will use it. The current situation has made it the universities that promote the development of solid virtual learning environments, with which a methodological change in the teaching-learning process is encouraged (GARCÍA; GONZÁLEZ; RAMOS, 2010). However, this change will only be made if higher schools locate, experience, and evaluate forms of teaching and learning that fall within the principles underpinning the new knowledge society, which uses technologies within and outside the classroom.

There are several factors that lead to the development of current teaching/learning. According to García (1999) it was sociopolitical advances, the need to learn throughout life, the decay of conventional systems, advances in the sciences of education, technological transformations and, in recent months, the emergence of the Covid-19 in the world, which have established virtuality as a reality. EVA helps to publish, evaluate, advise and have diverse academic spaces that allow to establish the constant communicative interaction 
between the participants (VASQUEZ; ARANGO, 2012). Part of the educational process is to know how contact and participation between students, teachers and virtual space is being generated with the aim of having a successful education.

Until some time ago, most universities only trained hard skills, thus calling for the skills needed for the development of a profession, since these skills were considered necessary to obtain good employment and success at the job level; over the years, however, evidence has shown that these skills are not predictive of professional success (EXTREMERA; FERNÁNDEZ-BERROCAL, 2004). According to Guerra-Báez (2019) soft skills are different from social skills, since the latter are part of the first and form skills to learn, analyze, manage time and innovate. Accordingly, soft skills go beyond interaction with others, as they help to be part of citizenship, respect human rights and be able to resolve conflicts.

Currently, graduates of different specialties require interaction skills about their technical knowledge, this because the absence of social and emotional skills are not always covered in universities and must be reinforced with programs that allow them to be obtained (NERI; HERNÁNDEZ, 2019). The objective of every professional is to meet the demands of the academic, work and society environment, since, unlike students, a professional must seek opportunities in the labor market by helping himself from the learning obtained. If these skills are worked and honed during undergraduate, they could positively help them become successful professionals. To do this, parents, university and students need to change their current vision, in addition to reflecting and understanding that places of study are a source for developing soft skills (NERI; HERNANDEZ, 2019).

For Ortega, Febles and Estrada (2016) soft skills have become a necessity for "cross-cutting" labour issues, so they need to be worked on since childhood. While these skills should be trained at an early age, where technological development strategies and learning strategies are implemented, they should also be developed, as mentioned above, in university schools where students, teachers and the same institution are aware of this need.

Canettieri, Paranahyba and Santos (2021) highlight in their research the importance of soft skills in the Common National Curriculum Base (BNCC) for the Baccalaureate. For his part, Rodríguez- López (2018), points out the importance of the use of new technologies, generating an enormous capacity for cooperation available to both 
teachers and students. While Cardoso (2016) maintains that in ancient times "for the teacher, technology was only a complement to the curriculum, not a tool that could help promote learning", a totally different aspect from today, added to virtuality forced by the pandemic. With regard to the relationship between the variables in this study, Mora and Arce's research (2020) recognized the importance and relevance of the use of virtual mode, which helps foster the development of soft skills. This work not only involved teachers but also students, and in both cases, they intend to include activities that strengthen the afore mentioned skills. This is because organizations currently apply for professionals who have these skills; therefore, technological tools allow them to be used and developed. According to Romero and García (2019) the virtual environment contributes to students trained in a remote model can be able to the develop soft skills.

For his part, Alfaro (2018) corroborated the significant relationship between virtual classroom use and skills learning. For this author, the good use of the virtual classroom favors the learning of personal skills and attitudes. In the same line, Celi and Lindley (2020) propose the creation of a service focused on developing soft skills to strengthen university education from an innovative approach.

Finally, because the confrontation with COVID-19 imposes significant challenges for university students regarding the use of virtual technologies and their impact on the skills put into the academic process, it is decided to carry out this research with the aim of determining the relationship between the perception of interaction in the classroom and the level of soft skills in students of the subsidiary in Arequipa of a private Peruvian university.

\section{Materials and method}

The present is a relational type of research as it aims to determine the relationship between the perception of interaction in the virtual classroom of teachers and level of soft skills of students of higher cycles of the subsidiary in Arequipa of a private Peruvian university in 2020. It is also a cross-sectional or transsectional study because the information is analyzed at a single time.

The composition of the population was 1,200 university students of high levels cycles (VII, VIII, IX and X cycle) from which a sample of 507 subjects $(47.9 \%$ female and 
$52.1 \%$ male) with ages between 19 and 35 years was extracted, with an average of 22.15 and a standard deviation of 2.26 years. An incidental non-probabilistic procedure was used for selection, considering the students who were assistant at the time of the application of the instrument.

About the instruments applied, these were:

a) For the variable "perception of classroom interaction" an adaptation to virtual education of the Classroom Interaction Estimation Scale (EEIA), created by Barrón (2018), whose final nomenclature is Inter-Action Estimation Scale in Virtual Classroom (EEIAV), was used. The instrument consists of thirty items, which correspond to a five-level scale: Never (1), Almost Never (2), Sometimes (3), Almost Always (4) and Always (5). Evaluates three dimensions: 1. Linear interaction (11 items) 2. Polygonal interaction (10 items) 3. Post-active moment (9 items).

b) For the variable "soft skills", was used the instrument developed by Morocho (2017) The instrument called Soft Skills Scale (EHB) (with an application scope for adolescents and adults) aims to measure the processes involved in emotional behavior. This instrument can be applied individually or collectively. When it comes to application time, scaling requires an average of 10 to 15 minutes. The instrument consists of 30 items and has a scale of 4 levels.

Both instruments were applied virtually using Google forms to the sample in the virtual classrooms of the subsidiary's professional schools in Arequipa of a Peruvian university. Participation in research was promoted by teachers who teach courses in selected cycles. Prior to this activity, the corresponding permits were requested and personalized training was carried out in order to ensure the correct collection of the data. The students, after being consulted, fulfilled this task without any academic or monetary pressure.

\section{Results and discussion}

The following paragraphs set out the results obtained after the information collection and processing process. 


\subsection{Psychometric analysis}

\section{Virtual Classroom Interaction Estimation Scale (EEIAV)}

The psychometric analysis of the EEIAV concludes that the items have homogeneity indices ranging from .824 (item 19) to .659 (item 1) being these significant as they far exceed the minimum values set by criterion Kline (2000) of 0.20 , so it can be said that the items on the room perception estimation scale have correct homogeneity rates.

With regard to the reliability coefficient (see table 1 in annexes), this was obtained using the internal consistency method, with a .961 Cronbach alpha being calculated based on the 30 items on the scale. The analysis concludes that the EEIAV has very high reliability.

The construct validity of the EEIAV (see table 2 in annexes) was obtained through exploratory factor analysis. The Kaiser-Meyer-Olkin index was .976, demonstrating this value that the instrument has explanatory potential, while Bartlett's sphericity test is significant as it is the Chi-square of 13395,591 and $p-0.00$ being less than $p<.05$, demonstrating that it is relevant to perform a factorial analysis with the resulting data.

Finally, exploratory factor analysis through the main components method establishes the formation of two factors that account for $63,926 \%$ of the entire variance. This makes it possible to conclude that the EEIAV has an optimal construct validity.

\section{Soft Skills Scale (EHB)}

The reliability of the EHB items (see table 3 in annexes) was evaluated using the internal consistency method, obtaining a Cronbach alpha value of .944 for the 30 items also having homogeneity indices ranging from .202 (item 6) to .745 (item 13), being greater than Kline's criterion (2000) of 0.200 . It can therefore be concluded that the scale enjoys reliability.

The construct validity of HB E (see table 4 in annexes) was evaluated through exploratory factor analysis. The Kaiser-Meyer-Olkin index was worth .943, highlighting its proper explanatory potential. In addition, Bartlett's sphericity test is significant, being the Chi-square of 8359.236 and the $p<.05$. Exploratory factor analysis used the main 
component method, which concludes that the scale has five dimensions that allow $59,134 \%$ of the entire variance to be explained. It can therefore be concluded that the EHB has construct validity.

\subsection{Descriptive analysis}

Analyzing the goodness of adjusting variables to the normal curve by testing Kolmogorov-Smirnov (see table 1) obtained statistics with low values for the virtual classroom interaction perception model and the scale of soft skills, concluded that the data do not have a normal distribution.

Table 1 - Kolmogorov-Smirnov's normal curve goodness analysis

\begin{tabular}{lccc}
\hline & Statistical & Kolmogorov-Smirnov & Gis. \\
\hline Perception of virtual & .127 & Gl & .000 \\
classroom interaction & .068 & 507 & .000 \\
Soft skills & Source: Own elaboration.
\end{tabular}

\subsection{Variable results}

Table 2 shows that, in terms of the perceived usefulness of the virtual classroom interaction perception model, it achieves an average value of 4.28 equivalents on the Likert scale of "almost always". The same goes for soft skills, obtaining a score of 3.34, which is equivalent to "almost always", making it clear that the vast majority of students of the university analyzed from the last cycles, state that they almost always perceive compliance with the evaluated elements, both in perception of interaction in virtual classroom and in soft skills.

Table 2 - Descriptive results of independent structures of the Virtual Classroom Interaction Perception Model and soft skills

\begin{tabular}{lccccc}
\hline & $\mathrm{N}$ & $\begin{array}{c}\text { Minimu } \\
\mathrm{m}\end{array}$ & Maximum & Average & $\begin{array}{c}\text { Standard } \\
\text { deviation }\end{array}$ \\
\hline $\begin{array}{l}\text { Perception of virtual classroom } \\
\text { interaction }\end{array}$ & 507 & 1 & 5 & 4.28 & .645 \\
$\begin{array}{l}\text { Soft skills } \\
\text { Valid N (by list) }\end{array}$ & 507 & 1 & 4 & 3.34 & .527 \\
\hline \multicolumn{5}{c}{ Source: Own elaboration. } \\
\end{tabular}

Educ. Form., Fortaleza, v. 6, n. 3, e5297, set./dez. 2021

DOI: https://doi.org/10.25053/redufor.v6i2.5297

https://revistas.uece.br/index.php/redufor/index 


\subsection{Results of the relationship between variables}

As both variables are non-normal, Spearman's Rho will be used as a hypothesis testing statistic. Table 3 shows the existence of a positive weak relationship between the perception of virtual classroom interaction and soft skills in students. The correlation is .114. The size of the effect is medium, being 0.3376389 , also validating the relationship and proving that it exists and is important. In terms of statistical power, the value exceeds 0.80 , obtaining the value of 0.950 , these results can be generalized to the entire population of university students studied.

Table 3 - Correlation of variables Perception of virtual classroom interaction and Soft Skills

\begin{tabular}{llc}
\hline & & Skills / Soft \\
\hline Perception of interaction & Spearman's Rho & $0.142^{*}$ \\
in virtual classroom & Sig. (bilateral) & 0.0110 \\
& $\mathrm{Q}$ & 0.3376 \\
& $1-\beta$ & 0.950 \\
$\mathrm{~N}$ & 507 \\
\cline { 2 - 3 } & Note: The correlation is significant at level 0.05 (2 queues).
\end{tabular}

Source: Own elaboration.

These results allow to accept the hypothesis raised for this research, since there is a significant and direct relationship between the perception of interaction in virtual classroom and the Soft Skills, although the relationship between the two variables is weak.

There is no research like the present that allows corroborate the results; however, it is relevant to highlight the study of Zhang (2012) who administered the skill scale in a course of computer science and data, and after factorial analysis, two dimensions emerged: soft and soft skills, obtaining 67 percent of the variance. Items on the evaluation scale passed a reliability test with Cronbach $\alpha$ values greater than 0.70 . This research also tested the reliability of the instrument to evaluate soft skills, obtaining a Cronbach alpha of 0.994 and after the factorial analysis five dimensions were obtained to explain $59,134 \%$ of the entire variance. Zhang (2012) also stressed the importance of preparing future IT professionals to develop their soft skills by communicating with end users, resolving conflicts, and bringing together different roles toward a common goal. 
For its part, the study of Caggiano et al. (2020) determined the importance of soft skills by obtaining that the engineers of the sample under consideration were able to express positive and negative ideas and feelings in balance with the reference mean, although they sometimes struggled to establish personal relationships. In this research the students studied show that they almost always perceive compliance with the elements evaluated, both in perception of interaction in virtual classroom and in soft skills. This importance was also corroborated by Sharma and Sharma (2010) who concluded that engineering graduates with purely technical knowledge are no longer a guarantee for a successful career, requiring in addition to soft skills.

On the other hand, Lindsey and Rice (2015), in their research on "Interpersonal Skills and Education in Traditional and Online Classroom Environments", conclude that students could benefit from the time, training, experience and practice of interpersonal skills in an online environment. This research corroborates this by concluding that there is a positive weak relationship between the perception of virtual classroom interaction and soft skills in students at the university analyzed.

Regarding the importance of the proper interaction of teachers in virtual classrooms, Pineteh (2012) corroborates the results of this research by concluding in its study that "complementarity" is the most convenient teaching approach for students because it can address its diversity in this virtual learning space, as well as promoting quality interactions between peers and collaborative learning. This result is also corroborated by Blaine (2019), in his research on interaction and presence in the virtual classroom, which concludes that the coding scheme shows that more can be done to communicate both expectations and the process of communication between students and teachers in online and combined courses.

Silva (2008), for its part, in its research on the interactions of teachers in a virtual learning environment, corroborates in its results a positive assessment for the virtual course, the role of the tutor and the platform and regarding the interventions that arise between the tutor and the participants in an interactive context that, at first, requires that the interaction of the participants be personal, although they gradually become more collaborative. This research also perceives an adequate interaction of the teacher with students through the virtual classroom. 
Martin, Parker and Deale (2018) conclude that student interaction and, therefore, learning, was aided by live communication that occurred through the virtual classroom. Abdous and Yen (2010) disagree with this, noting that the mode of delivery (face-to-face, satellite transmission, and live video streaming) was not a useful predictor for self-pervert interaction between the student and the teacher.

Finally, LaPointe and Gunawardena (2004) stated that the computer-mediated conferencing experience had a moderate direct effect on self-formed peer interaction and had a strong direct effect on self-formed learning outcomes.

In view of this data, the proper interaction of the teacher in the virtual classroom is important, for this, it must promote the development of soft skills in university students, allowing them to gain a competitive advantage in the labor market, because they seek the strengthening of the human being from personal components that contribute to generate optimal interpersonal relationships.

It remains to replicate this research in other university entities and at other training levels, highlighting the need to build, modify or transform teaching practice in order to foster a virtual higher education scenario interested in the parallel development of being and doing.

\section{References}

ABDOUS, M.; YEN, C. A predictive study of learner satisfaction and outcomes in face-toface, satellite broadcast, and live video-streaming learning environments. Internet and Higher Education, v. 13, n. 4, p. 248-257, 2010.

ALFARO, A. Relación del uso del aula virtual y el aprendizaje de habilidades y actitudes personales en alumnos de la carrera de Administración Bancaria del Instituto Superior Certus. 2018. 86 p. Tesis (Maestría en Ciencias de la Educación) - Programa de Postgrado em Ciencias de la Educación, Universidad Nacional Enrique Guzmán y Valle, Lima, 2018.

BARRÓN, M. Habilidades blandas para mejorar la interacción en el aula en docentes de la institución educativa "Ricardo Palma" de Acopampa, Carhuaz- 2017. 2018. 128 p. Tesis (Doctorado en Administración de la Educación) - Universidad Cesar Vallejo, Trujillo, 2018. 
BLAINE, A. Interaction and presence in the virtual classroom: an analysis of the perceptions of students and teachers in online and blended Advanced Placement courses. Computers \& Education, v. 132, p. 31-43, 2019.

CAGGIANO, V. et al. Soft skills in Engineers, a relevant field of research: exploring and assessing skills in Italian Engineering students. Ingeniería e Investigación, Bogotá, v. 40, n. 2, p. 81-91, 2020.

CANETTIERI, M.; PARANAHYBA, J.; SANTOS, S. Habilidades socioemocionales: del BNCC a las aulas. Educação \& Formação, Fortaleza, v. 6, n. 2, e4406, 2021. DOI: https://doi.org/10.25053/redufor.v6i2.4406. Available at: https://revistas.uece.br/index.php/redufor/article/view/4406. Access on: June, 10 $10^{\text {th }}, 2021$.

CARDOSO, A. Pro-tecnologia: uma abordagem de formação inicial de professores para o uso das tecnologias digitais. Educação \& Formação, Fortaleza, v. 1, n. 3, p. 50-70, 2016. DOI: https://doi.org/10.25053/edufor.v1i3.1890. Available at: https://revistas.uece.br/index.php/redufor/article/view/113. Access on: June, $10^{\text {th }}, 2021$.

CELI, V.; LINDLEY, M. Implementación de una empresa de servicios educativos para el desarrollo de habilidades blandas que refuercen las competencias profesionales de los universitarios. 2020. Tesis (Investigación en Ingeniería Industrial) - Universidad de Lima, Lima, 2020.

EXTREMERA, N.; FERNÁNDEZ-BERROCAL, P. El papel de la inteligencia emocional en el alumnado: evidencias empíricas. Revista Electrónica de Investigación Educativa, Ensenada, v. 6, n. 2, p. 1-17, 2004.

GARCÍA, L. Historia de la Educación a Distancia. Revista Iberoamericana de Educación a Distancia, Madrid, v. 2, n. 1, p. 2-27, 1999.

GARCÍA, A.; GONZÁLEZ, V.; RAMOS, C. Modelos de interacción en entornos virtuales de aprendizaje. Tonos Digital, Murcia, v. 19, p. 1-27, 2010.

GUERRA-BÁEZ, S. Una revisión panorámica al entrenamiento de las habilidades blandas en estudiantes universitarios. Psicología Escolar e Educacional, Bogotá, v. 23, p. 1-11, 2019.

HASSAN, Y. et al. Arquitectura de la información en los entornos virtuales de aprendizaje. Aplicación de la técnica card sorting y análisis cuantitativo de los resultados. El Profesional de la Información, Barcelona, v. 13, n. 2, p. 93-99, 2004. Available at: http://profesionaldelainformacion.com/contenidos/2004/marzo/2.pdf. Access on: June, $10^{\text {th }}, 2021$.

KLINE, P. The handbook of psychological testing. 2. ed. London: Routledge, 2000. 
LAPOINTE, D. K.; GUNAWARDENA, C. N. Developing, testing and refining of a model to understand the relationship between peer interaction and learning out-comes in computer-mediated conferencing. Distance Education, UK, v. 25, n. 1, p. 83-106, 2004.

LINDSEY, N.; RICE, M. Interpersonal skills and education in the traditional and online classroom environments. Journal of Interactive Online Learning, [S.I.], v. 13, n. 3, p. 126136, 2015.

MARTIN, F.; PARKER, M.; DEALE, D. Examining interactivity in synchronous virtual classrooms. The International Review of Research in Open and Distance Learning, Athabasca, v. 13, n. 3, p. 227-261, 2012.

MORA; F.; ARCE, J. El e-learning como potenciador de las habilidades en la enseñanza de las ciencias de la administración: el casi de la Universidad Estatal UNED de Costa Rica. Ensayos Pedagógicos, Heredia, v. 15, n. 2, p. 233-252, 2020.

MOROCHO, A. Propiedades psicométricas de la escala de habilidades blandas en personal administrativo de la UGEL AYABACA. 2017. Tesis (Título de Profesional de Psicología) - Universidad Cesar Vallejo, Trujillo, 2017.

NERI, J.; HERNÁNDEZ, C. Los jóvenes universitarios de Ingeniería y su percepción sobre las competencias blandas. Revista Iberoamericana para la Investigación y el Desarrollo Educativo, Guadalajara, v. 9, n. 18, p. 1-24, 2019.

ORTEGA, C.; FEBLES, J.; ESTRADA, V. Una estrategia para la formación de competencias blandas desde edades tempranas. Revista Cubana de Educación Superior, La Habana, v. 35, n. 2, p. 35-41, 2016.

PINETEH, E. Using virtual interactions to enhance the teaching of communication skills to information technology students. British Educational Research, London, v. 43, n. 1, p. 85-96, 2012.

RODRÍGUEZ-LÓPEZ, M. Grupos de trabajo, un medio para mejorar el desempeño en el campo de la CCSS en la educación secundaria a través de las TIC. Educação \& Formação, Fortaleza, v. 3, n. 7, p. 16-23, 2018. DOI: https://doi.org/10.25053/redufor.v3i7.169. Available at: https://revistas.uece.br/index.php/redufor/article/view/169. Access on: June, $10^{\text {th }}, 2021$.

ROMERO, M.; GARCÍA, A. Teamwork and business management simulation in the virtual classroom. Gestión de la Innovación en Educación Superior, Santiago de Chile, v. 4 , n. 1, p. 93-114, 2019.

SHARMA, G.; SHARMA, P. Importance of Soft Skills Development in 21st Century Curriculum. International Journal of Education \& Allied Sciences, [S.I.], v. 2, p. 39-44, 2010. 
SILVA, J. Teachers' interactions in a virtual learning environment: a comprehensive approach. Interactive Educational Multimedia, Barcelona, v. 16, p. 66-86, 2008.

VÁSQUEZ, C.; ARANGO, S. Estrategias de participación e interacción en entornos virtuales de aprendizaje. Anagramas, Medellín, v. 10, n. 20, p. 95-108, 2012.

ZHANG, A. Peer Assessment of Soft Skills and Hard Skills. Journal of Information Technology Education: Research, [S.I.], v. 11, p. 155-168, 2012.

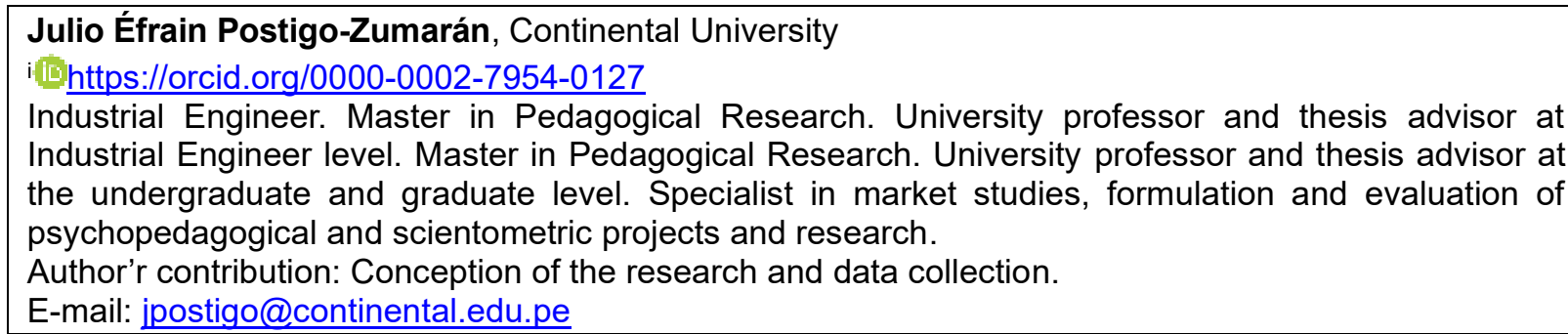

\section{Dennis Arias-Chávez, Continental University}

ii. https://orcid.org/0000-0003-1500-8366

Doctor in Education, Master in Hispanic Philology, Master in Higher Education and Bachelor of Literature and Linguistics. Professional specialist in thesis advice, research applied to the social sciences, scientific knowledge management and academic regulations for scientific production.

Author'r contribution: Methodological development and data collection.

E-mail: darias@continental.edu.pe

\section{Teresa Ramos-Quispe, National University of San Agustín de Arequipa \\ iii 1 https://orcid.org/0000-0003-4607-4745}

Degree in Literature and Linguistics from the San Agustín University of Arequipa (Peru), a degree in Secondary Education from the Catholic University of Santa María (Arequipa, Peru), a master's degree in Applied Linguistics from the National University of San Agustín and a master's degree in Hispanic Lexicography from the Royal Spanish Academy and the University of León in Spain.

Author'r contribution: Drafting of results and discussion.

E-mail: tramosq@unsa.edu.pe

Responsible editor: Lia Machado Fiuza Fialho Ad hoc experts: Luis Mattos and Milagrosa Collantes

\section{How to cite this article (ABNT):}

POSTIGO-ZUMARÁN, Julio Éfrain; ARIAS-CHÁVEZ, Dennis; RAMOS-QUISPE, Teresa. Perception of virtual classroom interaction and level of soft skills in college students.

Educ. Form., Fortaleza, v. 6, n. 3, e5297, 2021. Available at:

https://revistas.uece.br/index.php/redufor/article/view/5297 


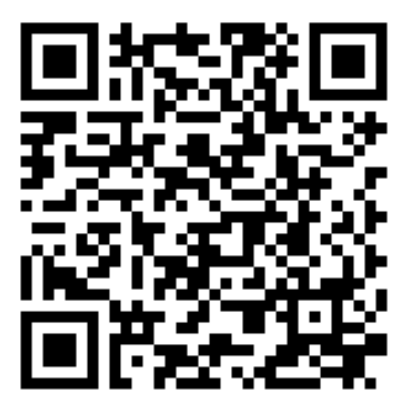

Received on March 31 $1^{\text {th }}, 2021$.

Accepted on June 29th 2021.

Published on July $12^{\text {th }}, 2021$. 